\title{
THE TEACHING OF EFL VOCABULARY IN THE INDONESIAN CONTEXT: THE STATE OF THE ART
}

\author{
Bambang Yudi Cahyono \\ Universitas Negeri Malang, Malang \\ Utami Widiati \\ Universitas Negeri Malang, Malang
}

\begin{abstract}
There has been extensive literature on the teaching of vocabulary of English as a foreign language (EFL vocabulary) in the Indonesian context. However, a comprehensive analysis on the teaching of EFL vocabulary in this country has been a rare endeavour. This article aims to underpin various issues of the teaching of EFL vocabulary and relate them to a wider context of second/foreign language vocabulary teaching and review results of research as well as current practices of EFL vocabulary teaching and learning in the Indonesian context. It is expected that this article could provide an outline of the teaching of EFL vocabulary and some recommendations for future research and practices.
\end{abstract}

Key words: teaching, EFL, vocabulary, Indonesian context

Vocabulary, in addition to grammar and pronunciation, is one of language elements considered necessary for language mastery. Vocabulary is defined as "all the words in a particular language" (Wehmeier, et al., 2005:1707), whereas vocabulary teaching, as Furneaux (1999) states, deals with "the selection and presentation of words (lexis) for learners" (p.367). Vocabulary teaching aims at enabling learners to understand the concepts of unfamiliar words, gain a greater number of words, and use words successfully for communicative purposes. Thus, good vocabulary mastery supports mastery of each of the language skills, both receptive (listening and reading) and productive (speaking and writing). 
For example, in reading, learners' vocabulary size affects their comprehension of a reading text (Nuttall, 1989), while in writing, vocabulary contributes to the success in writing compositions up to $20 \%$ of the achievement level (Hartfiel, et al., 1985).

As far as the history of second/foreign language teaching methodologies is concerned, vocabulary has been viewed differently depending on which method is fashionable. Eminently respectable under the Grammar Translation Method and the Reading Approach, vocabulary was then on far from being regarded as of pivotal importance in language learning. According to Seal (1991), there was even a period when "too much vocabulary learning was regarded as a positively dangerous thing" (p. 296). This means even though learners have a rich repertoire of English words, they might not be able to produce coherent sentences to convey ideas. The emergence of the Audio-lingual Method (ALM), for example, elevated grammar teaching but kept vocabulary learning minimum. As the main purpose of language teaching in the ALM was to establish the basic phonological and grammatical patterns of the language through habit formation (Seal, 1991:297), vocabulary seemed to be suppressed.

The view that vocabulary learning was of secondary importance in second language pedagogy still went on even though the ALM had been less popular. In the area of second language research, the same neglect could be readily observed. Until approximately late 1980s developments in research seemed to have neglected the area of vocabulary acquisition in the second language context. According to Meara (1984), the limited research in the area of vocabulary was caused by two major reasons. First, attention has been greatly focused on grammatical element of language because this element was believed to be the most important basis to build linguistic theories. One example was the publication of Chomsky's (1957) Syntactic Structures, which was followed by extensive discussion by and voluminous publications from other linguists and applied linguists. Second, appropriate models that can explain acquisition of second language vocabulary were not available in the literature and this hindered better understanding of the role of vocabulary in second language teaching and learning. The dominant structuralism's view adopted by the ALM that language is a habit formation, for example, manifested in the application of pattern practice and drills for improving speaking skill in second language teaching, leaving a narrow space for creative use or the teaching of vocabulary that is important for mastering language skills as well. 
The 1980s, thus, have seen a shift in the status of vocabulary (Furneaux, 1999:368). Given little priority in the past, vocabulary has been viewed as a core component of language proficiency. As Nation (2002) states, "vocabulary growth is such an important part of language acquisition that it deserves to be planned for, deliberately controlled and monitored" (p. 267). Vocabulary learning is thus not to be left to look after itself. It receives greater attention in many textbooks and language programs (Furneaux, 1999:369). For example, in their edited book discussing the nature of vocabulary, vocabulary acquisition, and vocabulary pedagogy, Schmitt and McCarthy (1997) noted a number of books on vocabulary published in the end of 1980s and early 1990s, indicating the awakening of vocabulary teaching and research studies. Their book, claimed as presenting "the state of the art in vocabulary studies" (p. 1), in fact, also contributed to the rich discussion of the study of vocabulary recently.

The importance of vocabulary in recent years has been elevated by three recent developments in the theory and practice of language teaching (Seal, 1991:297-298): the de-emphasis on grammar, the newly-placed emphasis on communication, and the perceived needs of students of English for academic purposes (EAP). With the emergence of communicative language teaching (CLT), formal studies of language become de-emphasized and the view of language teaching as facilitating learners to communicate becomes fostered. Additionally, increasing vocabulary provides the basis for developing students' ability in communicating. In the context of teaching EAP, there is an increased awareness of the need for providing ESL/EFL learners with more vocabularies to account for their success in academic studies. As Seal (1991) puts it, “... there are signs that a new era is upon us in which the place of vocabulary in language learning process and as an area of research is being restored to respectability and prominence (p. 296).

More importantly, the computerized analysis of language data by lexicographers and researchers has resulted in the ability to work on vocabulary with considerably more confidence (Harmer, 2000). From a corpus of millions of words, computers can give information about, for example, how often words are used and in what linguistic contexts. As a result of such knowledge, it is reasonably easier to discuss word meaning, word-use extension, collocations, and the grammar of words.

The growing importance of vocabulary has been evident not only in second/foreign language teaching and learning in a wider context of the world, but also in the Indonesian context of EFL. A great number of Indonesian writers, in 
fact, considered vocabulary as essential as grammar (e.g., Mukminatien, 1994) and recommended that vocabulary be given a greater emphasis in the Indonesian curriculum (e.g., Kweldju, 2005; Priyono, 2004). Responding to this trend, this article reviews what has been going on in the Indonesian context as far as vocabulary learning and teaching is concerned. It starts with the description of various issues on the role of vocabulary in second/foreign language learning and examines the place of EFL vocabulary in the English curriculum. Furthermore, it explores current practice and results of research on the teaching of EFL vocabulary in the Indonesian context. Finally, this article outlines some insights for future practice and research on the teaching and learning of EFL vocabulary in Indonesia.

\section{VOCABULARY TEACHING AND RESEARCH: THEORETICAL PER- SPECTIVE}

Theoretically, the teaching of second/foreign language vocabulary and research on acquisition of second/foreign language vocabulary can be given separate attention. However, these two areas of concerns are complementary in that vocabulary teaching can get insights from vocabulary research, while vocabulary research can initiate from conditions encountered in vocabulary instruction. In this section, each of the two areas of concerns will be discussed separately, and then the relation of the two areas will be highlighted.

Two major questions concerning vocabulary teaching and learning are as follows: Should vocabulary teaching be done directly, or should vocabulary acquisition take place through exposure? According to Seal (1991), the answers to those questions will have implications on how vocabulary is taught in second/foreign language classroom, be it unplanned or planned vocabulary teaching. Unplanned vocabulary teaching refers to vocabulary being taught unsystematically, arising because one student has a problem with a word that has come up in the lessons, or because the teacher thinks that an important vocabulary item is unknown to the majority of the students. In contrast, planned vocabulary teaching involves two types: one incidental to the objective of the lesson and the other one specifically designed as vocabulary lesson.

Quite similarly, Hunt and Beglar (2002) describe three approaches to vocabulary teaching and learning: incidental learning, explicit instruction, and independent strategy development. Incidental learning is learning vocabulary as a 
by-product of doing other language activities, for example, reading and writing. As reviewed by Hunt and Beglar (2002), several studies have confirmed that extensive reading and listening contribute to the incidental vocabulary learning. In contrast, explicit instruction refers to intentional learning of vocabulary through instruction, which is essential for beginning students whose lack of vocabulary limits their reading ability. Finally, independent strategy development concerns equipping learners with strategies for vocabulary learning.

With the three approaches-indirect, direct, and independent strategiespotentially enabling students to learn vocabulary, it is necessary for teachers to carefully plan their vocabulary teaching. A wide variety of activities and exercises should be employed so that all of these approaches can take place. Examples of these activities and strategies include inferring from context and guessing from context (incidental learning or indirect instruction); building a large sight vocabulary, integrating new words with the old, providing a number of encounters with a word, describing a target word, facilitating imaging and concreteness, elaborating semantically such as through semantic feature analysis, semantic mapping, ordering, pictorial schemata, and collocation (explicit or direct instruction); and involving the students in learning through individual participation, collaboration with classmates, and self-reflection, as well as training the students in using different dictionaries and in making vocabulary notebooks (independent learning strategies) (S?kmen, 1997). Regardless of the variety, current argument on vocabulary learning suggests the usefulness of a systematic approach to vocabulary teaching over incidental vocabulary learning. This is because, as Nation (2002) indicates, incidental learning bears some limitations due to the fact that many second language learners cannot read independently because of limitations in their vocabulary knowledge. While the teaching of second/foreign language vocabulary has gained many insights from the three approaches, research on second/foreign language vocabulary acquisition has been based on a field wider than classroom setting. The following section focuses on research on second/foreign language vocabulary acquisition by elaborating first Meara's $(1984,1997)$ work on the relation of word and lexis.

In his article as cited earlier, Meara (1984) stated that one reason for the limited research on vocabulary acquisition was the unavailability of appropriate model for vocabulary acquisition. To contribute to the discussion of vocabulary acquisition, in his later article, Meara (1997) provided a model of the relation between a word (W) and lexicon (L). According to Meara, a word is connected in some way to the main body of lexicon. All words in this body of lexicon are 
related in various ways to other words as indicated by arrows of various directions and various ways of relation. The model of the relation of a word and lexicon is shown in Figure 1.

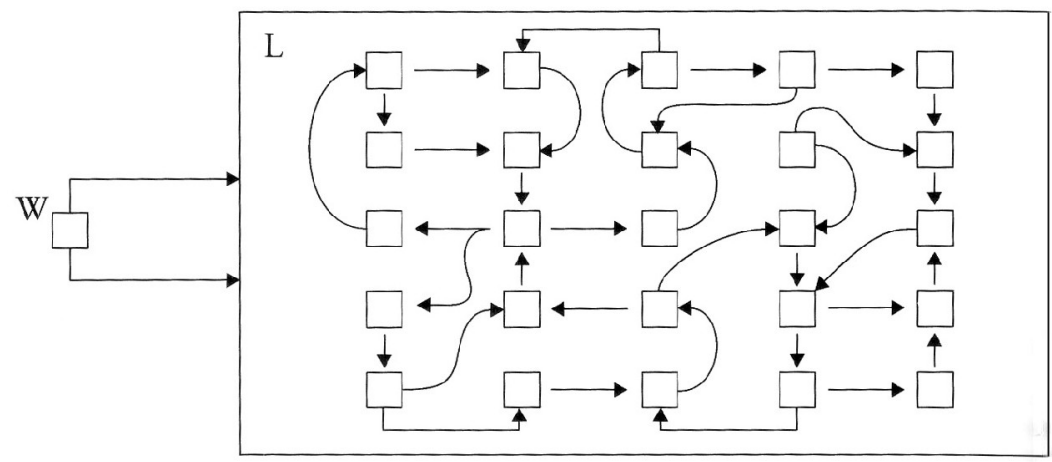

Figure 1. A model of the relation of a word (W) and lexicon (L) (Meara, 1997:120)

Although Meara's (1997) research has showed us that one word is connected with other words, it does not explain further how this connection facilitates vocabulary learning. Responding to this issue, Ellis (1997) examined the role of memorization in vocabulary acquisition. Ellis stated that memory works through short-term and long-term processes. Words stored as short-term representations are easily forgotten, whereas long-term representations of words are retained longer. Words learned through short-term representation can be retained as long-term representation through rehearsal or practice, resulting in the "chunking of working memory contents" (Ellis, 1997 p. 139) or "lexicon" (Meara, 1997:120). This implies that words that are related to other words as "chunks" can be learned more easily than isolated words. Referring to what S?kmen (1997) elaborated above, in practice this word relation can be taught through the use of chunking vocabulary exercises such as semantic mapping, ordering, pictorial schemata, and collocation. Such word relation, either linguistically or conceptually, is also found in the use of "metaphor" (Kweldju, $2005,2006)$ or words used to suggest concepts different from their literal meanings. 


\section{EFL VOCABULARY IN ENGLISH CURRICULUM}

The place of EFL vocabulary in the Indonesian curriculum seems to be changing in accordance with the existing curriculum, perceived from the changing objectives and methods of English instruction in Indonesia. The 096/1967 Ministerial Decree on English instruction stipulates that the objective of English instruction in secondary schools is to equip the students with a working knowledge of English through the development of the language skills of reading, listening, writing, and speaking in that order (Huda, 1999:127). In the 1960s, the curriculum adopted a version of the ALM. Under the ALM, it can be assumed that grammar teaching was so elevated that vocabulary teaching was suppressed. As Seal (1991:297) suggests, this dominant teaching methodology resulted in an immediate and devastating effect on vocabulary teaching and research; vocabulary learning should be kept to a minimum.

A modified version of the ALM was adopted in the next curriculum, implying quite a similar practice of vocabulary teaching in the Indonesian education system. However, as can be seen in the English textbooks used in the junior as well as the senior high schools, vocabulary teaching in the 1975 curriculum seemed to gain greater attention. Each unit of lesson always presented a list of vocabulary that students had to focus on. This indicates the uniform lists of words that secondary school students throughout Indonesia had to master. The sets of vocabulary items to teach had been decided beforehand.

The 1984 curriculum was said to implement a communicative method in the English instruction in Indonesia. Officially, the English instruction was geared toward the objectives of enabling junior-high-school students to develop English language skills of reading, listening, speaking, and writing in thematic situations in accordance with their individual developmental levels and interests, using 1000 word-level and appropriate structures and senior-high-school students using 2500 word-level and appropriate structures (Depdikbud, 1986).

The 1994 curriculum adopted the "meaningfulness approach" (pendekatan kebermaknaan), a version of the communicative approach in order that the objective of English instruction is not misinterpreted (Huda, 1999:142). To avoid misinterpretation of the approach, according to Huda (1999:150), some principles of the implementation are stated explicitly, one of which is the mastery of communicative competence. From this statement, it can be seen that language 
components (grammatical structures, vocabulary, and pronunciation) are considered necessary; linguistic form is used as the organizing principle.

The 2004 and 2006 curricula, the so-called Competency-Based Curriculum (CBC) and the school-level curriculum or KTSP (kurikulum tingkat satuan pendidikan), emphasize the development of communicative competence covering linguistic competence, discourse competence, socio-cultural competence, and strategic competence. Linguistic competence, in particular, includes such components as grammar, vocabulary, and pronunciation. Under the four stages of teaching and learning process suggested by the curriculum, namely Building Knowledge of the Field (BKOF), Modelling of the Text (MOT), Joint Construction of the Text (JCOT), and Independent Construction of the Text (ICOT), vocabulary teaching is supposed to be dealt with at the very first stage. In the BKOF stage, teachers are expected to focus on grammar, to elicit students' vocabulary, and to have sharing activities of the topic. However, the word focus is left to teachers to decide. Such a practice implies the lack of uniformity of what words secondary-school students should master.

The review suggests that regardless of its place in the curriculum, vocabulary seems to be considered necessary. This is even so as secondary school students are required to have sufficient vocabulary power to do English final examination successfully. This implies that teachers need to work on developing students' vocabulary systematically. Nevertheless, what vocabulary lists teachers have to help learners master is influenced by teachers' understanding of the existing curriculum. At some time, the uniformity of word lists to teach makes it easier for teachers to work on the vocabulary development. At some other time, when the existing curriculum does not suggest explicitly what word lists to teach, teachers' sensitivity of what vocabulary the students might need is highly required.

\section{EFL VOCABULARY RESEARCH AND PRACTICE IN INDONESIA}

As mentioned previously, vocabulary is important to support mastery of language skills. Accordingly, vocabulary research and practice are usually related to the teaching and learning of language skills, with a special emphasis on the relation between vocabulary and reading. In Indonesia, in particular, research studies on vocabulary are needed to fully understand the role of vocabulary in second or foreign language learning and to overcome teaching and/or 
learning problems related to vocabulary acquisition (Mukminatien, 1994). In this section, some reports on ESL/EFL vocabulary teaching and learning as well as research are reviewed, beginning from what research showed regarding lexical competence of Indonesian learners of English.

Compared to research on the teaching and learning of ESL/EFL, research on lexical competence of Indonesian learners of English is less flourishing. This, perhaps, was caused by the common situation that vocabulary learning or teaching was considered secondary or neglected as it used to be. However, notable research reports were Nurweni's (1997) study of Indonesian students' EFL vocabulary size and Kweldju's (1999) study of Indonesian students' collocation abilities.

Nurweni (1997) sought to find out whether secondary school graduates knew the 2000 most frequent words and the 808 academic words as the target words. The results of her study indicated that on average, the 324 subjects knew 987 of the 2000 most frequent words, and 239 of the 808 university words, making up 1226 words in total. It was then inferred that the students might have known a far smaller number of words which are far less frequent. It was also very likely that they forgot, thus did not acquire yet, most of the words already exposed to them. Theoretically, the students were expected to acquire 14 words a week; in fact, they only acquired about 7 words a week, which according to Nurweni (1997) was a real waste of time, money, and energy in English teaching. The loss of so many words already exposed suggested the need for increasing the number of word repetitions.

In her study, Kweldju (1999) examined English department students' knowledge of collocations. Collocation refers to the "co-occurrence of a word and another word or more in the near vicinity" (Priyono, 1999:98). Examples of (lexical) collocation include spicy food, lenient rules, heavy drinker, and week tea. Sixty students who were involved in Kweldju's study were given a list of 25 items of collocations. These students were asked to determine whether they were familiar with these items and given five possible options: known, fairly known, little known, hardly known, and unknown. The results of the study showed that in general the students were able to supply only a few expected collocations, whereas most of the students were familiar with several collocations. These findings suggest that many Indonesian learners of English were not aware of collocations and, as Kweldju (1999) recommended, "collocations should be brought to the attention of the learners and deliberately learned" (p. 60). 
Studies reported above suggest the importance of vast vocabulary knowledge, more particularly vocabulary size. Accordingly, when dealing with vocabulary size, teachers need to start from the most frequently-used words, meaning that information on vocabulary frequency lists is necessary. This does not mean that teachers need to provide students with extensive lists of vocabulary as learning resources. However, as Nation and Waring (1997) suggest, teachers "need to have reference lists to judge whether a particular word deserves attention or not, and whether a text is suitable for a class" (p. 17). Thus, lists of vocabulary serve as a guide for teachers to determine what vocabulary to teach and how many words to teach within a particular period of time.

In addition to discussing the importance of knowledge on vocabulary, it is also necessary to focus on what teachers have conducted to improve students' lexical competence. Mukarto (1989), for example, suggested that games be used to deal with the problems of vocabulary teaching and learning. Examples of games include go fish where students play cards and ask each other for cards to make pairs and hangman where students think of a word and write a number of lines indicating the number of letters of the words that other students should guess. Proved to be one of the best solutions, games could be played by students outside the class hours, helping them overcome their poor mastery of vocabulary.

Other research studies have explored the role of vocabulary learning and/or teaching strategies. A research study conducted by Merawati (2003), for example, showed that the teaching of guessing meaning of words from context could improve reading skills and strategies. Applying a classroom action research design, Merawati had the students study vocabulary by following three cycles. First, the students were given short texts and asked to practice guessing word meaning from context. Second, they were introduced to patterns of expository texts with more difficult words and asked to follow the guessing process more naturally. Finally, the students were given longer texts containing unknown or nonsense words that can stimulate them to find out more clues to the word meaning from more extensive textual context. Merawati's study showed that practice on guessing meaning from context helped students understand word meaning from sentences and paragraphs within the text and understand the meaning of a large amount of conceptual words.

In her exploration of the use of strategies in understanding difficult words in reading texts, Kusumarasdyati (2006) found that Indonesian learners used strategies varying from looking up either monolingual or bilingual dictionary, 
examining context cues, and skipping unfamiliar words. However, the uses of these strategies were mainly based more on interest than innate strategy use. This suggests, as Kusumarasdyati said, that each individual learner has a unique strategy he/she is likely to use in understanding unfamiliar words.

While some research has examined vocabulary in relation to language skills, some has investigated vocabulary as a separate language component. Cahyono (1993) examined the effect of teaching topical vocabulary on students' vocabulary mastery. Students in his study were divided into two groups: the experimental group being taught how to develop vocabulary size using topical vocabulary (e.g., new vocabulary was presented topically such as weather, plants, and animals), while the control group was taught word formation process or vocabulary building (e.g., analyzing the meaning of derivational affixes such as suffix -less in the word careless). The results showed that there was no significant difference between the two methods of vocabulary learning, suggesting that any method of the two contributed to the learners' improved achievement on vocabulary tests applied in the study.

To some authors (e.g., Kweldju, 2004, 2005; Priyono, 1999, 2004), vocabulary is believed to be the most significant element of English language teaching (ELT). More importantly, they suggested that solution of problems of ELT lies in the good handling of vocabulary. Based on a series of in-depth research studies, Kweldju $(2004,2005)$ argues that students' single source of problem in learning English is vocabulary. Therefore, she proposed that ELT in Indonesia should be lexically-based, meaning that English teaching and learning strategies should be made in such a way that the strategies could lead to vocabulary acquisition. As strategies relate also to the age factor, Kweldju (2004) stated that adult learners should be taught to learn EFL vocabulary more deliberately, whereas children should be let learn English vocabulary more incidentally through reading children's literature. Similarly, Priyono (2004:26) stated that the main problem of Indonesian EFL students is their limited vocabulary. He then emphasized the importance of vocabulary teaching (i.e., facilitating the process whereby EFL input leads to learners' EFL vocabulary intake). According to Priyono $(1999,2004)$, as lexical properties entail grammatical aspects, the teaching of EFL vocabulary will support the teaching of aspects of grammar and meaning, thus reducing the necessity to teach grammar.

Some other authors (Prayogo, 1997; Pranowo, 2006) consider that teachers have significant roles in developing students' abilities to develop their EFL vocabulary learning. This is because vocabulary is both an important part of all 
content learning (Cahyono, 1999) and a significant part of any literacy program. Considering the crucial place of vocabulary, Prayogo (1997) suggests that various available strategies for vocabulary learning be implemented in the classroom. Picture clues, sight words, context clues, structural analysis and dictionary use are among the many available strategies which can be utilized as temporary aids as well as independent strategy. Like Prayogo, Pranowo (2006) values the importance of strategy teaching, more particularly the teaching of text-attack skills. Pranowo's argument was based on his observation that most Indonesian learners lack strategies in dealing with new words. He then suggests that in dealing with new words, teachers need to work on a number of aspects that contribute to more fruitful English language learning. These aspects include the pronunciation of the word, the spelling, the word class, the meaning, and the use.

With the development of computer as a tool for storing and using words and texts, there has been a tendency in applying computer-based and corpusbased vocabulary teaching. In his study on how students perceived vocabulary teaching using computer, Dwijatmoko (2006) found that, in general, the students thought the process of learning could be conducted successfully with the help of computer. From this finding, Dwijatmoko concluded that a computerbased vocabulary teaching "is a good way for teaching vocabulary" (p. 17). Furthermore, he stated that the students perceived positively the interaction or practice sessions, the classroom atmosphere, and the modes of computerassisted vocabulary learning. In short, Dwijatmoko found computer helpful for students' vocabulary learning development and suitable with their learning styles.

Another strand in the use of computer to teach vocabulary deals with the use of corpora. Corpora refer to a large collection of spoken and written words or texts stored in a computer database. Corpora provide some ready-to-use language teaching materials such as the frequency lists of words and concordances of words. In Indonesia, recently published articles have addressed the use of corpora in ELT (e.g., Husada, 2006, 2007). For example, in his article discussing the nature of corpora, Husada (2006) stated that the frequency lists of words are useful to help both students and teachers know which of the words fall and autumn is more frequently used in relation to their contexts such as American or British English. In his later article, Husada (2007) provided an example of investigating the use of the exclamatory words damn, damn it and dammit using corpora-based analysis. It is interesting to know that although the 
three expressions are interchangeably, the exclamatory word damn, as he stated, "is used about three times as often as damn it and almost four times as frequently as dammit" (p. 42). The use of corpus-based data such as these can be a useful insight for EFL vocabulary teaching. It should be noted, however, that Husada's example is merely for the sake of analysis, as the word damn in our context is considered vulgar. Thus, teachers should choose words that are needed for communication by the students and, at the same time, are sound ethically.

\section{INSIGHTS FOR FUTURE EFL RESEARCH AND PRACTICE IN INDONESIA}

Increasing learners' vocabulary has apparently been considered necessary. Language teachers and researchers have realized the importance of vocabulary as an area worthy of effort and investigation. Referring to the historical background and current situation of the teaching of EFL vocabulary in Indonesia, we will try to highlight some issues that could be useful for future EFL research and practice in this country. First, research areas that seem worth exploring are how EFL learners acquire and organize lexicon as well as how they enlarge that lexicon. As reviewed before, the limited research on vocabulary acquisition is likely due to lack models of vocabulary acquisition and the underlying relation between words and lexicon. Data regarding these might contribute to the research body of either descriptive studies or acquisition studies. Researchers might be interested in describing responses to such questions as: How are words actually used in discourse? How are words structured and organized? How are words related? How are individual lexical items related to the lexicon web as a whole? In terms of vocabulary acquisition, researchers might want to explore problems such as: Are some words more difficult than others? What makes a word more difficult to learn? What strategies are suitable for facilitating vocabulary acquisition?

Second, language teachers need to explore various techniques in the teaching of vocabulary. Using intensive and extensive reading activities as a means of exposing learners to vocabulary in context seems to be the most practical for classroom applications. Besides, increasing learners' vocabulary requires independent strategy development, implying the need for training learners in the use of strategies for vocabulary learning. Independent learners, as Seal (1991) 
suggests, tend to become effective dictionary users and effective word readers. In addition to teaching activities, it is then necessary to train learners in the use of strategies for recording words as well as reviewing them. This is useful to make learners aware that they need to refer to any new word they know again and again in order for the word to be retained.

Finally, those afore-mentioned issues should also be highlighted and worked on in teacher-training institutions. Vocabulary studies can be included as significant parts of the program so that teacher trainees can develop awareness of the importance of vocabulary teaching. As more emphasis is given to vocabulary, they should be better informed in terms of issues related to research and practice of vocabulary teaching and learning.

\section{CONCLUSION}

The need to learn vocabulary has been viewed differently in different language teaching methods. The fashionable method contributed to the decision as to how to place vocabulary teaching in the overall program of language teaching. In the Indonesian context, the place of vocabulary teaching has also undergone changing depending on the existing curriculum. Nevertheless, considering the context, vocabulary appears to be the most significant element in the sense that good handling of vocabulary is likely to lead to solution of ELT problems. Strategies of English teaching and learning should be geared toward vocabulary acquisition.

This article has reviewed various issues of vocabulary teaching in the broader context of ESL/EFL teaching as well as in the Indonesian context and has indicated that much still can be done for future EFL research and practice in Indonesia to contribute to the research body of descriptive or acquisition studies concerning vocabulary. Additionally, teachers as well as teacher trainees should be equipped with much better understanding of how necessary increasing learners' vocabulary is in the success of second/foreign language acquisition. Three approaches of indirect, direct, and independent strategies appear potential in enabling students to learn vocabulary, which teachers can make use of in planning their vocabulary teaching. 


\section{REFERENCES}

Cahyono, B. Y. 1993. Pengaruh Pengajaran Kosakata Topikal pada Peningkatan Penguasaan Kosakata Bahasa Inggris [The effect of topical vocabulary teaching on the improvement of English vocabulary mastery]. Bahasa dan Seni, 21(2): 54-63.

Cahyono, B. Y. 1999. Content Area Textbooks as Sources for Vocabulary Learning. Jurnal Ilmu Pendidikan, 6(Special edition): 403-412.

Chomsky, N. 1957. Syntactic Structures. The Hague: Mouton.

Depdikbud [Ministery of Education and Culture]. (1986). Kurikulum Sekolah Menengah Tingkat Atas: Garis-garis Besar Program Pengajaran Bidang Studi Bahasa Inggris [Senior high school curriculum: Basic course outline of the English subject matter]. Jakarta: Departemen Pendidikan dan Kebudayaan.

Dwijatmoko, B. B. 2006. Computer-based Vocabulary Teaching: The Students' Perception. A paper presented at the $54^{\text {th }}$ TEFLIN International Conference, Salatiga.

Ellis, N. C. 1997. Vocabulary Acquisition: Word Structure, Collocation, Wordclass, and Meaning. In Schmitt, N. \& McCarthy, M., Vocabulary: Description, Acquisition, and Pedagogy (pp. 122-139). Cambridge: Cambridge University Press.

Furneaux, C. L. 1999. Vocabulary Teaching. In Johnson, K. \& Johnson, H. Encyclopedic Dictionary of Applied Linguistics (pp. 367-369). Oxford: Blackwell.

Harmer, J. 2000. The Practice of English Language Teaching ( $3^{\text {rd }}$ ed.). Essex: Pearson Education.

Hartfiel, V. F., Jacobs, H. L., Zinkgraft, S.A., Wormuth, D. R., \& Hughey, J. B. 1985. Learning ESL Composition. Rowley, M. A.: Newbury House.

Huda, N. 1999. Principles of Teaching and Learning: Trends and Issues. Malang: State University of Malang Press.

Husada, H. S. 2006. Seeking some Possibilities of Bridging Corpora into the Classrooms. English Edu, 6(2): 93-107.

Husada, H. S. 2007. The Corpus-based Investigation of the Word 'Damn'. English Edu, 7(1): 34-44. 
Hunt, A., \& Beglar, D. 2002. Current Research and Practice in Teaching Vocabulary. In Richards, J. C. \& Renandya, W. A. (Eds.), Methodology in Language Teaching: An Anthology of Current Practice (pp. 267-272). Cambridge: Cambridge University Press.

Kusumarasdyati. 2006. Verbal Reports of Proficient Readers in Coping with Unfamiliar Words. Jurnal Ilmu Pendidikan, 13(3): 160-166.

Kweldju, S. 2004. Lexically-based Language Teaching: An Innovative Step for ELT in Indonesia. In Cahyono, B. Y. \& Widiati, U. (Eds.), The Tapestry of English Language Teaching and Learning in Indonesia (pp. 37-56). Malang: State University of Malang Press.

Kweldju, S. 2005. Lexically-based Language Teaching: Metaphor for Enhancing Learning. Indonesian Journal of English Language Teaching, 1(2): 164-177.

Kweldju, S. 2006. Lexically-based Language Teaching: Metaphor in English for Specific Purposes. Jurnal Ilmu Pendidikan, 13(3): 151-159.

Kweldju, S. 1999. English Department Students' Collocation Abilities. TEFLIN Journal, 10(1): 48-62.

Meara, P. 1984. The Study of Lexis in Interlanguage. In Davies, A., Criper, C., \& Howatt, A. P. R. (Eds.), Interlanguage (pp. 225-235). Edinburgh: Edinburgh University Press.

Meara, P. 1997. Towards a New Approach to Modelling Vocabulary Acquisition. In Schmitt N. \& McCarthy, M. (Eds.), Vocabulary: Description, Acquisition, and Pedagogy (pp. 109-121). Cambridge: Cambridge University Press.

Merawati, M. V. J. 2003, Oktober. Building on Students' Weaknesses to Practice Guessing Meaning from Context and Improve Reading Skills and Strategies. Paper presented at the $51^{\text {st }}$ TEFLIN International Conference, Bandung.

Mukarto, F. X. 1989. Vocabulary Building Through Games: The Communicative Way of Teaching and Learning Vocabulary. TEFLIN Journal, 2(1): 59-74.

Mukminatien, N. 1994. Masalah Leksis dalam Bahasantara [Lexical Problems in Interlanguage]. Bahasa dan Seni, 22(2): 140-150. 
Nation, P., \& Waring, R. 1997. Vocabulary Size, Text Coverage, and Word Lists. In Schmitt, N. \& McCarthy, M. Vocabulary: Description, Acquisition, and Pedagogy (pp. 6-19). Cambridge: Cambridge University Press.

Nation, I. S. P. 2002. Best Practice in Vocabulary Teaching and Learning. In Richards, J. C. \& Renandya, W. A. (Eds.), Methodology in Language teachIng: An Anthology of Current Practice (pp. 258-266). Cambridge: Cambridge University Press.

Nurweni, A. 1997. How many Words do Senior High School Students Acquire per Week. TEFLIN Journal, 8(1): 103-115.

Nuttall, C. 1989. Teaching Reading Skills in a Foreign Language. London: Heinemann.

Pranowo, J. 2006. Word-attack Skills for Indonesian Learners. TEFLIN Journal, 17(2): 113-120.

Prayogo, J. A. 1997. Models of Vocabulary Teaching Strategies. English Language Education, 3(1): 29-36.

Priyono. 1999. Towards a Reduction of Grammar Teaching: A Lexical Analysis. TEFLIN Journal, 10(1): 88-102.

Priyono. 2004. Logical Problems of Teaching English as a Foreign Language in Indonesia. In Cahyono, B. Y. \& Widiati, U. (Eds.), The Tapestry of English Language Teaching and Learning in Indonesia (pp. 17-28). Malang: State University of Malang Press.

Schmitt, N., \& McCarthy, M. (Eds.). 1997. Vocabulary: Description, Acquisition, and Pedagogy. Cambridge: Cambridge University Press.

Seal, B. D. 1991. Vocabulary Learning and Teaching. In Celce-Murcia, M. (Ed.), Teaching English as a Second or Foreign Language (pp. 296-311). Boston: Heinle \& Heinle.

S?kmen, A. J. 1997. Current Trends in Teaching Second Language Vocabulary. In Schmitt, N. \& McCarthy, M. (Eds.), Vocabulary: Description, Acquisition, and Pedagogy (pp. 237-257). Cambridge: Cambridge University Press.

Wehmeier, S., McIntosh, C., Turnbull, J., \& Ashby, M. (Eds.). 2005. Oxford Advanced Learner's Dictionary of Current English. Oxford: Oxford University Press. 